\title{
The Business Family as the Business Model of Our Time
}

\author{
James Hoopes \\ Babson College, Boston, USA \\ hoopes@babson.edu
}

\begin{abstract}
The information technology has reduced the cost of business transactions large managerial corporations are giving way to small family business firms. It is good change because family businesses could not only aim to sustain the family economically but also could aim nurturing children. The role of ethics in family business is has not been studied systematically. This paper has argued that family firms are more socially responsible that non-family firms because family firms are breeding ground for core family values. This paper also argues that business literature should lay emphasis on virtues and character based business in place of value and culture based business. To manage for organizational virtue and character is to treat ethics as an end in itself. To manage by values and characters is to treat ethics as means for some ulterior motive. If employees are told that they should be honest because it pays then profit may trump in case of a conflict. The combination of family virtues and business can make the family busines as moral model or moral leadership for all types of business in this era of high demands for accountability.
\end{abstract}

Keywords: Family Firm, Ethics, Virtues, Character, Culture, Moral Leadership

\section{Introduction}

Family business is the most exciting field of commerce today, the field with the most potential to shape the future, not just economically but socially and morally. Information technology, by lowering the costs of transactions, has significantly reduced and in some cases even removed the competitive advantage of large managerial corporations. No wonder that small entrepreneurial firms have captured the business imagination of our era.

Among those small entrepreneurial firms, family businesses have an ethical advantage giving them the greatest potential to improve not just the practice of business but society in general. This potential ethical advantage in family business and the reasons for it are not as widely understood as they should be. A recent survey of family business scholarship reports that the role of ethics in family firms has not been systematically studied (De Massis, et. al., 2012).

What would it mean to study fully the ethics of family business? Among other things it would mean that family virtues would be taken more seriously as a factor in family business. The order of words in the phrase "family business" suggests that "family" is simply a means to an end, an adjective identifying a particular way of organizing a business. 


\section{Ethics of Family Business}

To understand the ethics of family business more fully we need to recognize that sometimes the more accurate phrase would be "business family." Sometimes "business" should be the adjective and "family" the noun because the purpose of family business can transcend a family's economic needs. Sometimes a family uses a business for nonbusiness purposes.

Family businesses often aim not just to sustain the family economically but also to accomplish another great objective. They aim to create, maintain, and perpetuate good habits of behavior in themselves and their offspring. In a phrase, family businesses often aim to achieve a virtuous character, especially for their children.

Families with moral aspirations often try to educate their children in some mix of virtues such as courage, compassion, generosity, industry, independence, integrity, loyalty, love, prudence, persistence, and resilience. Aiming to pass a strong character on to the next generation, such families provide children with opportunities to practice good behavior and to develop good habits. Play, friendship, school, sports, and intra-family relations are opportunities to practice good conduct and thus build a virtuous character. A "business family" extends its educational and character-building opportunities into the commercial sphere.

As others have noted, a family firm is therefore "a breeding ground for the development of 'core' family virtues" (Orozco \& González, 2013). The appeal of economic selfsufficiency as a motive for family enterprise is long heralded. Far less remarked is the opportunity that family business provides for "home schooling" in virtue.

The potential interrelations of family virtue and business profit range along a spectrum. At one end would be the pure "family business" aiming strictly at profit. At the other end would be the pure "business family" focused entirely on using the business for family purposes such as building a virtuous character in the family and its progeny.

Probably, there is not and never has been such thing as a pure "family business" focused entirely on profit. Still less likely is a pure "business family" focused entirely on character. Juxtaposed against each other, "family business" and "business family" are idealized constructs useful for helping us recognize the range of economic and noneconomic purposes motivating a family to go into business. Firms may lean more heavily one way or the other, but the large majority are surely driven by both family and business concerns.

Scholars have observed that in family business "the boundaries between the family and the firm are blurred" and "emotions slow back and forth" (Gomez-Meijia et al., 2011). It is therefore not a simple matter of family resources serving the purposes of the business. The business also serves the purposes of the family, including the sustaining of the family's character, its virtue.

It should scarcely be surprising, therefore, that family businesses have important things to teach the rest of the business world about ethics. For example, social responsibility is sometimes called the business model of the $21^{\text {st }}$ century. Research suggests that family businesses are more socially responsible than non-family firms (Berrone et al., 2010 and Dyer \& Whetten, 2006). It has also been suggested that family firms' social responsibility is due to "intangible reasons that go beyond economic considerations" (Gomez-Mejia, et $a l ., 2011)$. Among those intangibles is surely the attention of business families to sustaining a virtuous character not only in the firm but in the family. 


\section{Virtue Ethics}

Many families come naturally to the practice of "virtue ethics" even though they may never have heard that somewhat technical phrase from moral philosophy. Despite not knowing the philosophical label for what they are doing, such families nevertheless aim to cultivate habits of good conduct in their children. According to Aristotle, the West's most prominent virtue ethicist, virtue is a "habit." We acquire habits by practice. If one wishes to develop the virtue of integrity, one needs to practice acting honestly again and again until such action becomes habitual, becomes a part of one's character. The same goes for other virtues such as courage, compassion, justice, and so on.

Why do many families who try to develop good habits in their children do not know that they are teaching something called "virtue ethics"? At least one of the reasons is that virtue ethics has largely disappeared from popular moral discourse in the West. While virtue ethics thrives in philosophy texts, popular discussion focuses on "values". Discussion of business ethics and social responsibility is no exception. A recent study finds that "there has been almost no discussion of virtue ethical frameworks in the analysis of decision making in organizations" (Crossan, 2013).

A concern for virtue is not only alive but explicit in many Asian religious and philosophic traditions such as Islam, Hinduism, Buddhism, and Confucianism. So too, contemporary Christians in Asia often seem - to me at least - to place a more distinct and self-aware emphasis on virtue than do their co-religionists in the West.

I regret to observe that many Westerners have a low opinion of business ethics in Asia. This Western opinion smacks of moral arrogance, neocolonialism, and cultural egocentrism. Often, such opinions are based on the belief that the virtue of financial integrity is practiced less widely in Asia than in the West. Whether or not that is correct, Western critics of Eastern ethics are less prone to notice that the adherence in Asia to family loyalty, generosity, and compassion may well surpass the West's practice of such virtues.

But in any case, the important thing is not to claim that one region of the world is morally superior to another. I will argue in this paper that many Western businesses could learn something useful from Asia's more common or at least more explicit reliance on virtue ethics. But I do not wish to suggest any general moral superiority in Asia any more than I do in the West. There are many Western firms - family and otherwise - which in their actual practice, albeit not often in their self-descriptions, aspire and work for virtue.

The question of who is somehow "in the lead" in regard to ethics is both morally dangerous and morally irrelevant. The student of comparative business ethics ought not to ask whether one region is "better" than others. She ought only to ask how one region might learn and improve from the practice of another.

One of the advantages of trying to learn from others is that it may engender some selfreflection. For example, Asians' comparatively more explicit recourse to virtue ethics might lead Westerners to ask why their own society which used to regularly employ the concept of virtue no longer does so. Why has the West resorted instead to the concept of "values" which it increasingly imposes on the rest of the world?

\section{Values and Virtues}

The difference between "values" and "virtues" is the difference between the claim to be propelled by some internal standard for making ethical choices - a "moral compass," as 
popular Western discourse would have it - and on the other hand, believing that good conduct is a matter largely determined by the possession of good habits of external behavior. Where virtue obviously requires effort and practice, values are supposedly already in place or else easily adopted.

In popular moral discourse in the West, we can not only already possess the "values" we need but we can be sure that we have them. This naïve confidence in the ready availability of ethical self-knowledge is a little noticed result of the scientific revolution in the $17^{\text {th }}$-century West. Empirical observation led to reliable, scientific knowledge of the external world. So why shouldn't an inward glance produce similarly scientific knowledge of one's self? Many Westerners came to doubt traditional religious and moral cautions about the difficulty of self-knowledge (Hoopes, 1989).

Since the scientific revolution Western scientists and moral philosophers have slowly backtracked from belief that moral self-knowledge requires nothing more than an inward glance. For example, depth psychology, behaviorism, semiotics, and neural network research have shown the wisdom of ancient teachings that moral self-knowledge comes from examination of one's external behavior: "Ye shall know them by their fruits" (The Bible, Matthew 7:16). Notions that the self is difficult to fathom have re-entered popular discourse.

But popular discussion of business ethics - especially in the West and, increasingly, elsewhere -- is an exception to the growing awareness that moral self-knowledge is no easy matter. In business, many hold firmly to the view that one's self is readily knowable to anyone who cares to look inward for a moment. The notion that one can easily know what one values and that those values are good is too comforting to give up.

Our popular values talk makes business ethics a tool rather than a goal, as indicated by the title of a 20-year-old but still influential book, Managing by Values (Blanchard \& O'Connor, 1997). If we already know our values and know that they are good, we can rest on our moral laurels. There's no need to work on improving our ethics, no need for any effort to improve ourselves.

The only effort needed to manage by values is the work involved in expressing our supposed values or, as some would have it, Giving Voice to Values (Gentile, 2010). That approach actually takes the ethics out of business ethics. Such confidence in moral selfknowledge encourages us not to think about what's right and wrong but only about how to get others to act the way we want because we know we're right. A better approach for developing moral complacency which can slide into arrogance and unwitting corruption could hardly be devised.

Such superficial moral discourse infects much discussion of business ethics in the West. "Values-based management" has been a staple now for nearly half a century. Such ideas are taken very seriously in Western business schools and corporations where they inform organizational "values statements." "Talk is cheap" is a popular expression in the business world but values talk somehow gets a pass.

Family business is an exception. Virtue ethics still prevails in many family businesses. Yes, the language of values may be found in family businesses, increasingly in Asia as well as in the West. But often it is clear that even when family business people use the word "value" they are really referring to virtue. In Malaysia, for example, there is an admirable family businessman who often speaks of "values" but is critical of businesses which "put the vision mission only on the wall." He aims, in his company, to make the mission a matter of "heart," a matter of character (Yusof, et al., 2014). 
Many families, especially those engaged in child rearing, do not treat ethics as just a tool to achieve some other purpose. For those families, ethics is an end in itself. Such families often go beyond values talk and focus on objective behavior in order to encourage good conduct which can develop into good habits. With their focus on child rearing, business families are less likely than large, publicly held corporations to manage by values and culture. They are more likely to manage for virtue and character.

Just as virtue is an ethically more useful concept than values, so should character replace culture. As employed in popular business discourse, "culture" is just a word for the shared values which supposedly unite the members of an organization in a common purpose. Business ethics could be vastly improved by replacing the idea of organizational culture as a managerial tool in favor of what is already the ethical goal of many business families, the development of character.

\section{Character in Family Business}

Can a business organization have a character? The idea of group character has long been out of fashion. The concept of national character, for instance, can feel like a move toward stereotyping and bigotry. Yet when groups are not labeled by others but, instead, label themselves as aspirants for a virtuous character, their goals can be admirable and achievable. A century ago, one of the greatest philosophers of habit since Aristotle argued that "Esprit de corps, national sentiment, sympathy, are no mere metaphors." Personal identity or character can be formed by shared thoughts within groups or "corporations" no less than within individual bodies (Peirce, 1991).

To manage for organizational virtue and character is to treat ethics as an end in itself. To manage by values and culture is to treat ethics as a mere means to some ulterior and possibly amoral end. If employees are told, for instance, that they should be honest because it pays, profit may trump probity when they conflict.

Business leaders should treat virtue and character as goals, not tools. That is, instead of managing by values, business in general should follow the example of business families and managing for virtue. Instead of claiming moral self-knowledge in values statements, leaders should state virtues as goals. They should say to employees: "Here are our virtues goals. They represent the kind of character we want to have. Please act in a way that helps us develop the virtuous habits by which we can achieve those goals."

Treating virtues as goals is consistent with the way character building really works. Our personal experience confirms Aristotle's wisdom in thinking of virtues as "habits" developed through practice. For example, if we passed up an opportunity to cheat in school, we found it easier to do the right thing the next time the same temptation arose.

And sadly, personal experience teaches that just saying we have good values does not mean we will always act right. The danger of putting talk before deeds is why companies should not issue lofty values statements. As Aristotle saw, virtue is achieved not by words but by actions which become habits. Therefore, companies should issue statements of "virtue goals" only as the first step in the action of managing for those goals.

\section{Conclusions}

Business ethics and business profits are similar in at least one way. We should never rest on past performance. Stating values as if they are a done deal is like saying that investors should be concerned only with last year's earnings. Whether the objective is profit or 
character, money or virtue, a good business aims at better results in the future than in the past.

To manage by values is to treat ethics as a tool. To manage for virtue is to treat ethics as a goal. If business in general were to adopt the practice of managing for virtue and character, they would be following what is already the common practice of many business families.

The combination of family virtues and business can make the business family the moral model for all types of business in our era of exceptionally high demands for accountability. But real-life business families have their hands full already, trying for the sake of their children not only to make a profit but to manage for virtue. They can hardly be expected while fulfilling those responsibilities to offer moral leadership to the business world in general. Therefore, it will be up to family business scholars to help business families offer moral leadership to the rest of the business world. 


\section{References}

Aristotle (1889). The nicomachean ethics. London, England: George Bell.

Berrone, P., Cruz, C., Gomez-Mejia, L. R., \& Larraza-Kintana, M. (2010). Socioemotional wealth and organizational response to institutional pressures: Do family-controlled firms pollute less? Administrative Science Quarterly, 55, 82113.

Blanchard, Ken \& O'Connor, Michael (1996). Managing by values: How to put your values into action for extraordinary results. San Francisco: Berrett-Koehler.

Crossan, M., Mazutis, D., Seijts, G. (2013). In search of virtue: The role of virtues, values and character strengths in ethical decision making. Journal of Business Ethics, $113,567-581$.

De Massis, A., Sharma, P., Chua, J.H., Chrisman, J.J. \& Kotlar, J. (2012). State of the art of family business research. In A. De Massis, P. Sharma, J.H. Chua \& J.J. Chrisman (Eds), Family business studies, an annotated bibliography (pp. 10-46). Edward Elgar Publishing Limited, Cheltenham: United Kingdom.

Dyer, G. W. \& Whetten, D. A. (2006). Family firms and social responsibility: Preliminary evidence from the S\&P 500. Entrepreneurship Theory and Practice, 30(4), 785-802.

Gentile, Mary C. (2010). Giving voice to values: How to speak your mind when you know what's right. New Haven, Connecticut: Yale University Press.

Gomez-Mejia, L. R., Cruz, C., Berrone, P., and de Castro, J., (2011). The bind that ties: Socioemotional wealth preservation in family firms. The Academy of Management Annals, 5(1), 653-707.

Hoopes, James (1989). Consciousness in New England: From puritanism and ideas to psychoanalysis and semiotic. Baltimore: Johns Hopkins University Press.

Orozco C., Luz Elena and Gustavo Gonzalez C. (2013). Family firms and entrepreneurial families as breeding grounds for virtues. In Exploring transgenerational entrepreneurship: the role of resources and capabilities. Edited by Pramodita Sharma, Philipp Sieger, Robert S. Nason, Ana Cristina Gonzalez L. \& Kavil Ramachandran (Eds.), Edward Elgar Publishing Limited, Cheltenham: United Kingdom.

Peirce, Charles Sanders (1991). Man's Glassy Essence. James Hoopes (Ed.), Peirce on signs: Writings on semiotic by Charles Sanders Peirce, Chapel Hill, North Carolina: University of North Carolina Press.

Yusof, Mohar, Leilanie Mohd Nor \& James Edward Hoopes (2014). Virtuous CSR: An Islamic family business in Malaysia. Journal of Family Business Management, 4, 133-148. 